\title{
BIOLOGY, ECOLOGY AND VOLTINISM OF THE AUSTRALIAN SPONGILLAFLY SISYRA PEDDERENSIS SMITHERS (NEUROPTERA: SISYRIDAE)
}

\author{
by G. N. R. Forteath and A. W. Osborn
}

(with eight text-figures, eight plates and one table)

\begin{abstract}
Forteath, G. N. R. \& Osborn, A. W. 2012 (14:xii): Biology, ecology and voltinism of the Australian spongillafly Sisyra pedderensis Smithers (Neuroptera: Sisyridae). Papers and Proceedings of the Royal Society of Tasmania 146: 25-35. https://doi.org/10.26749/rstpp.146.25 ISSN 0080-4703. Queen Victoria Museum and Art Gallery, PO Box 403, Launceston, Tasmania 7250, Australia (GNRF* AWO). *Author for correspondence. Email: forteath@dodo.com.au
\end{abstract}

\begin{abstract}
The life stages of Sisyra pedderensis are described and statistical data from laboratory rearing experiments discussed. Novel sampling methods were used to obtain pupae from the field since adults were not attracted to black lights and the larval life cycle closed in the laboratory. The diel cycles of egg eclosion, full-fed larval emergence from aquatic habitats, and adult emergence are examined and illustrated. Morphological data are provided to identify the three larval instars. A comprehensive comparison of the biology of $S$. pedderensis and closely related overseas species is made. In Lake Pedder, this species of spongillafly was proved to be bivoltine, with overwintering larvae becoming imagines in early summer which was followed by a single summer generation.
\end{abstract}

KeyWords: Aquatic lacewing, bionomics, bivoltine, limnology, Lake Pedder, Tasmania, natural science, Sisyrapedderensis, Neuroptera.

\section{INTRODUCTION}

In Australia, spongillaflies (Neuroptera: Sisyridae) are relatively uncommon insects although two genera, Sisyra (nine species) and Sisyrina (two species), have been recorded (Smithers 1973, New 2000, Smithers et al. 2008). However, knowledge of the biology and ecology of Australian spongillaflies is very limited, and descriptions of life cycles are based on species from overseas.

Sisyra pedderensis Smithers, 2008 (Smithers et al. 2008) is the only spongillafly to be recorded from Tasmania where it occurs in Lake Pedder, the shores of which range from Northings 5264680 and 5235000 and Eastings 416550 and 448280 (GDA 94). Lake Pedder is an oligotrophic water body in the southwest wilderness of Tasmania covering $235 \mathrm{~km}^{2}$. The lake has been managed as a reservoir by Hydro Tasmania since 1972 and when at full capacity holds $3.3 \mathrm{~km}^{3}$ of water. More detailed information on the formation of the present Lake Pedder may be found in Osborn et al. (2008) and Forteath \& Osborn (2012).

We identified the presence of the larvae of $S$. pedderensis in the lake when collecting freshwater sponges, Radiospongilla pedderensis Osborn, Forteath \& Stanisic, 2008, during the winter of 1996 (Osborn et al. 2008). Later, during summer surveys of the aquatic fauna within some sheltered bays, we found large numbers of spongillafly cocoons spun in a variety of habitats. Subsequently, adult sisyrids were collected by sweeping hand nets among riparian vegetation around these bays, especially among clumps of cutting grass, Gahnia grandis (Labill.) S.T. Blake. We also discovered oviposition sites on the ventral surface of the leaves of G. grandis as well as in cracks and crevices of dead wood overhanging or adjacent to the water's edge.

More detailed investigations into the biology of $S$. pedderensis both in the field and laboratory followed. These included studies on reproduction, longevity, growth and development, and dormancy. Tauber \& Tauber (1978) and Clifford (1982) pointed out that these characteristics, when quantified by time, express information about the sum total of numerous biological processes and can conveniently be used to classify an insect's life cycle in terms of voltinism.
The aims of the study were, therefore: (1) to obtain meaningful biological and ecological data relating to an Australian species of sisyrid; (2) to make biological comparisons with overseas species; and (3) to interpret the life cycle of Sisyra pedderensis in terms of voltinism.

\section{MATERIALS AND METHODS}

\section{Field sites}

Sisyra pedderensis had been recorded at a number of sites around the shoreline of Lake Pedder (Smithers et al. 2008) and at Edgar Dam ( $\left.43^{\circ} 01^{\prime} 47^{\prime \prime S} 146^{\circ} 20^{\prime} 57^{\prime \prime} \mathrm{E}\right)$, a tarn which lies in close proximity to the southeastern end of the lake (fig. 1). An area of Starfish Inlet ( $\left.42^{\circ} 51^{\prime} 55^{\prime \prime} S 146^{\circ} 00^{\prime} \mathrm{E}\right)$ was selected for field studies of the terrestrial stages of the life cycle and the shallow water along the shoreline of Sprent Basin (42\%46'03"S 14559'19"E) for the collection of larvae and their host sponge $R$. pedderensis (fig. 1).

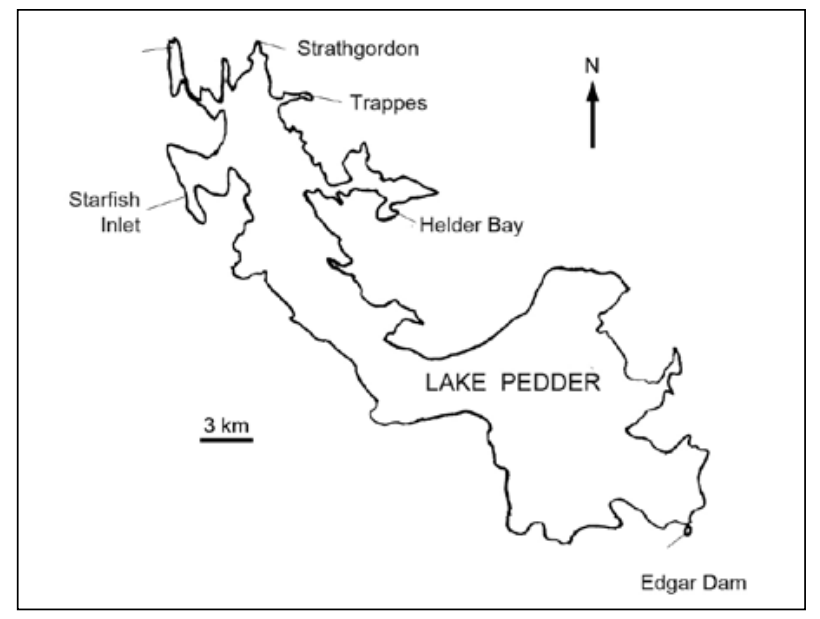

FIG. 1 - Map of sampling sites in Lake Pedder. 
Osborn et al. (2008) noted a large number of freshwater sponges encrusting the flooded timbers and shrubs in Starfish Inlet. On sampling these sponges, we discovered that they were preyed upon by larval spongillaflies but the depth of water $(3-4 \mathrm{~m})$ greatly restricted their collection here. Furthermore, access to the bay was possible only by boat which made sampling in winter difficult. The bay was ideal, however, for the collection of migrating full-fed larvae, and cocoons which were abundant in the summer months on the aerial limbs of the flooded timber. Adult insects and their eggs were common also among the riparian vegetation.

Sprent Basin was accessible by road and many of the rocks strewn along the shallows of the western shore were encrusted with sponges in water no more than $60-80 \mathrm{~cm}$ deep. These sponges were preyed upon by spongillafly larvae. This bay, therefore, had the advantage that both the larvae of $S$. pedderensis and their host sponges were able to be sampled all year round by wading out from the shore and picking up suitable rocks.

Ambient air temperatures were recorded at the Tasmanian Weather Bureau's weather station at Strathgordon and the water temperatures of Lake Pedder by a data-logger anchored I $\mathrm{m}$ below the water surface (fig. 2).

We collected cocoons for our laboratory cultures. Prising cocoons from fissures along the aerial limbs of flooded timbers was time-consuming and often resulted in physical damage to the enclosed pupae, so we wrapped hessian sacks $(80 \mathrm{~cm} \times 35 \mathrm{~cm})$ around tree trunks to act as artificial collectors (pl. 1). These were positioned $30-60 \mathrm{~cm}$ above the water surface of the lake using wool-bag staples. Each batch of sacks was left undisturbed for up to 14 days before being collected and replaced. On removal from the trees, the sacks were transported back to the laboratory and the cocoons individually harvested by snipping the surrounding hessian with scissors. Each cocoon was isolated in a $70 \mathrm{ml}$ Perspex medical container up to the time the imago emerged.

The diel cycle of migrating full-fed larvae was studied in a similar manner by fixing sack-collectors around the aerial trunks of submerged trees. Twelve collectors were positioned $30 \mathrm{~cm}$ above the water surface and replaced every three hours over a 24-hour period. The larvae present on the sacks after each interval were transferred singly into a $70 \mathrm{ml}$ container and observed until each had pupated.

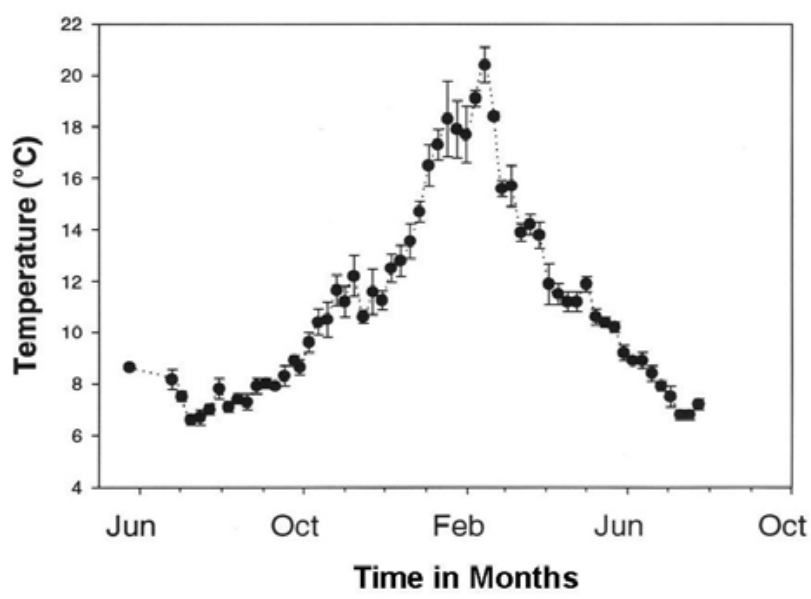

FIG. 2 - Mean water temperature profiles recorded over three years at a depth of $1 \mathrm{~m}$ in Lake Pedder.
Fifteen sack-collectors were deployed around suitable tree trunks in Starfish Inlet from early March to the end of April 2006 after which they were collected and the cocoons on them examined for overwintering prepupae. In addition, we collected cocoons in late March from aerial trunks and branches of submerged trees in Helder Bay (42 $51^{\circ} 58.21^{\prime \prime S}$ $\left.146^{\circ} 07^{\prime} 55.65^{\prime \prime E}\right)$, Trappes ( $\left.42^{\circ} 48^{\prime} 05.10^{\prime \prime S ~} 146^{\circ} 05^{\prime} 18.76^{\prime \prime E}\right)$, and from under the bark of peppermint gums, Eucalyptus nitida Hook. f. root stocks of Leptospermum lanigerum (Sol. ex Aiton), and among tussocks of $G$. grandis along the shore of Sprent Basin.

Light traps (8-watt black light fluorescent tubes) failed to attract the imagines of $S$. pedderensis. Therefore, adult insects of both sexes were collected during the day and night using hand-nets and specimen jars. Specimens were stored immediately in $70 \%$ ethanol and later dissected to reveal their gut contents.

To attract oviposition, nine wooden gates made from staves $125 \mathrm{~cm} \times 2.5 \mathrm{~cm} \times 2.5 \mathrm{~cm}$ each consisting of two vertical bars supporting three horizontal bars, and three pontoons each constructed from three weathered wooden fence palings $160 \mathrm{~cm} \times 13 \mathrm{~cm} \times 1.5 \mathrm{~cm}$ and placed end to end, were positioned at right angles to the shoreline of Starfish Inlet (42 $\left.51^{\prime} 59.40^{\prime \prime S} 146^{\circ} 00^{\prime} 24.06^{\prime \prime E}\right)$ when imagines were flying in January. Three gates were placed on the bank of the lake within $1 \mathrm{~m}$ of the water's edge, three in the water $1 \mathrm{~m}$ from the shore and the remaining three in water $10 \mathrm{~m}$ from the shore. The horizontal bars were situated $10 \mathrm{~cm}, 20 \mathrm{~cm}$ and $30 \mathrm{~cm}$ above the ground or water, respectively. The first section of each of the three pontoons was placed on the shore and the remaining two moored over the water. The height of the pontoon above the ground and water was $10 \mathrm{~cm}$. These structures were left in place for 14 days.

All clusters of eggs were counted on the pontoons. However, clusters were so numerous on the staves that three $\times 25 \mathrm{~cm}^{2}$ sub-samples were counted on each surface of each stake.

Larvae were collected at regular intervals from Sprent Basin and a method of identifying the three larval instars of $S$. pedderensis was developed based on external morphological features using both light and scanning electron microscopy.

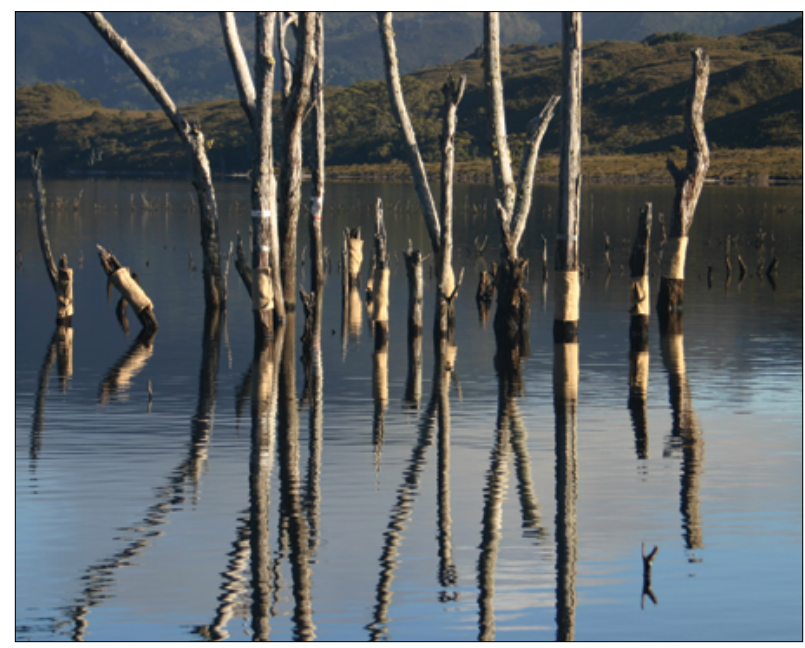

PLATE 1

Hessian sacks wrapped around tree trunks provide habitat for the construction of Sisyra pedderensis cocoons. 


\section{Laboratory}

Cocoons and imagines were held under conditions of natural light and seasonal day length at an ambient temperature of $20^{\circ} \mathrm{C}$; this being similar to the ambient air temperature at Lake Pedder in midsummer.

The suitability of several cage designs for keeping pairs of imagines were trialled. Pairs kept in modified $70 \mathrm{ml}$ Perspex medical sample jars and fed sucrose syrup (100 g water:200 $\mathrm{g}$ sucrose), were found to have the greatest longevity. These jars were modified as follows:

- Sufficient BlueTac ${ }^{\mathrm{TM}}$ adhesive was placed on the inside of the lid to support the shaft of a golf-tee, while the cup end served as a food receptacle.

- A small hole was drilled in the end opposite the lid and a length of wire inserted through it which supported a small block of wood cut from a well-fissured fence paling (2 $\mathrm{cm} \times 1.5 \mathrm{~cm} \times 1 \mathrm{~cm})$. The block was suspended a short distance above the golf-tee and acted as a roost for the pair by day and an oviposition site for the $q$ by night. The wooden blocks were harvested and replaced daily.

Pairs of virgin $\hat{O} \mathrm{x} q$ imagines placed in these modified containers were used to study courtship, mating, longevity and fecundity.

Eggs were counted by placing a block under a dissecting microscope while the hooked end of a medical splinterremover was passed under the silk protecting the clusters of eggs. The eggs were then prised out from within the fissures.

Duration of egg development and period of larval eclosion were determined by hanging wooden blocks on which there were clusters of eggs of known age inside inverted 70-ml containers. The lids of the containers were replaced by Scotch Tape $310^{\mathrm{TM}}$, the oviposition sites now coming to lie directly above the adhesive surface of the tape. On eclosion, larvae dropped from the wooden block, and were trapped on the adhesive surface below. The diel cycle of eclosion was established by hourly changes of the Scotch Tape. During the period of eclosion, light readings were recorded using a Digital Instruments Lux Meter model: LX1010B.

We also placed 10 batches of eggs and 25 pupae of known age in a Waeco incubator set at $10^{\circ} \mathrm{C}$ to investigate the effects of temperature on the development period of these two life stages.

\section{Life cycle in the laboratory}

Cocoons were collected on sack-collectors during the last two weeks of November. The $\mathrm{P}_{1}$ population of imagines selected for the trial consisted of 20 pairs of virgin $\widehat{\delta} \bar{\delta} \mathrm{x}$ 우, all of which emerged on the same night. Each pair was placed in a modified $70 \mathrm{ml}$ container.

On the first morning that oviposition was present on at least 15 of the 20 blocks, 10 were affixed to a wire running above the length of the water surface of an aquarium. The remaining five were suspended inside inverted 70-ml containers, the lids being replaced by Scotch Tape. The latter served as controls to confirm the time and day of eclosion of this particular cohort of $\mathrm{F}_{1}$ larvae.

$\mathrm{F}_{1}$ larval instars were on-grown in an acrylic aquarium, $120 \mathrm{~cm}$ long $\times 42 \mathrm{~cm}$ wide $\times 56 \mathrm{~cm}$ high, filled with $250 \mathrm{~L}$ of habitat water from Sprent Basin and filtered using both a JEBO 819 rapid mechanical sand-filter and a trickle-filter which passed the water over a bed of activated charcoal. Both systems were turned off for a period of 24 hours during larval eclosion from the eggs to avoid possible mechanical injury to newly hatched larvae and/or interference to larval settlement from water currents from influent water. The filter systems also were timed to turn off one hour before sunset to one hour after sunrise once third instar larvae were identified on the sponges, to avoid damage to full-fed larvae migrating from the water.

Water temperature in the aquarium was held at a constant $18^{\circ} \mathrm{C}$ to correspond with the mean water temperature of Lake Pedder in January and early February (fig. 2).

To minimise growth of filamentous unicellular algae over the surface of the sponges, the amount of natural daylight entering the aquarium room was reduced and the sides of the tank covered by cardboard from its base to a height of $20 \mathrm{~cm}$. Further shading was achieved through naturally occurring tannins in the habitat water. These measures reduced the light in the vicinity of the sponges to $\leq 100$ Lux.

Dissolved oxygen concentrations in the water were monitored daily using an Oxy-Tech Dissolved Oxygen Meter, and both total ammonia and $\mathrm{pH}$ of the water determined by the use of Merck water quality test kits.

Thirty green sponges, Radiospongilla pedderensis, were collected from Sprent Basin during the second week of December, each sponge encrusting the upper surface of a single rock approximately $8 \mathrm{~cm} \times 4 \mathrm{~cm}$. Before these were placed in the aquarium, they were examined under a microscope for the presence and removal of any spongillafly larvae. The sponge-encrusted rocks were then placed on the bottom of the aquarium in three clusters of 10 rocks each, the sponges facing towards the water surface.

A single sponge from each of the three rock clusters was inspected one day after the eggs hatched to confirm larval settlement, and a further sample taken on day 20 in order to monitor the progress of larval development.

Once third instar larvae were observed, each rock cluster was encircled by three lengths of fence paling, each $80 \mathrm{~cm}$ $\times 10 \mathrm{~cm} \times 1.5 \mathrm{~cm}$ which were weighted down by ceramic insulators. On being lowered over each rock cluster they formed a tepee-like structure. Hessian sacks were wrapped around each length of paling rising above the waterline. Thereafter, both palings and sacks were examined each morning for cocoons. Both the palings and sacks were replaced daily once the first batch of cocoons was observed.

Three days after larval emergence from the water ceased, the sponges were removed and examined under the microscope for any remaining larvae.

The $\mathrm{F}_{1}$ cocoons were harvested and placed individually in containers. On emergence of the imagines, 15 virgin $\delta \hat{O}$ and 15 virgin 90 were paired and each pair placed in a rearing container. The eggs laid each night were pooled into cohorts and on eclosion the $\mathrm{F}_{2}$ larvae were trapped on Scotch Tape and counted.

\section{RESULTS}

The collection of both cocoons and full-fed larvae from Starfish Inlet using sack-collectors was highly successful. Most collectors were found to have at least 20 cocoons spun on them and some attracted over 100 . The first cocoons were present by the second week of November and numbers were observed to peak between the last week in November and second week of December. Thereafter, new cocoons were present up to mid-March.

Full-fed larvae were present on collectors during the latter half of November and early December. Forty-two 
larvae were observed spinning cocoons on a batch of 15 sacks set overnight in the last week of November. The diel cycle of full-fed larvae leaving the lake is shown in figure 3. Some larvae started to leave the water before sunset but peak emergence was recorded between half an hour after sunset and midnight. Likewise some larvae continued to emerge for a short period after sunrise. Full-fed larvae lost their gills prior to leaving the water (pl. 2).

Larvae removed from the collectors commenced spinning their cocoons within an hour of being placed in a container and cocoons were completed within 10-12 hours. The prepupae metamorphosed into pupae 12-14 hours later.

No overwintering prepupae were found among the 173 cocoons examined on collectors retrieved at the end of April from Starfish Inlet. Imagines appeared to have emerged normally from 158 of these and a further nine contained mummified pharate adults. The remainder appeared empty and possibly had been parasitised by the parasitoid Trichomalopsis sisyrae Askew, 2010 (Forteath et al. 2010). At this time in the year we also failed to find prepupae in cocoons collected from the other widely-dispersed sampling sites at Helder, Trappes and Sprent Basin, respectively.

The crop and gut of adult insects collected in the field contained a clear fluid and a number of particles, possibly fungal spores. No pollen grains or fragments of arthropod cuticle were observed in the crop or gut when viewed under high-power light microscopy.

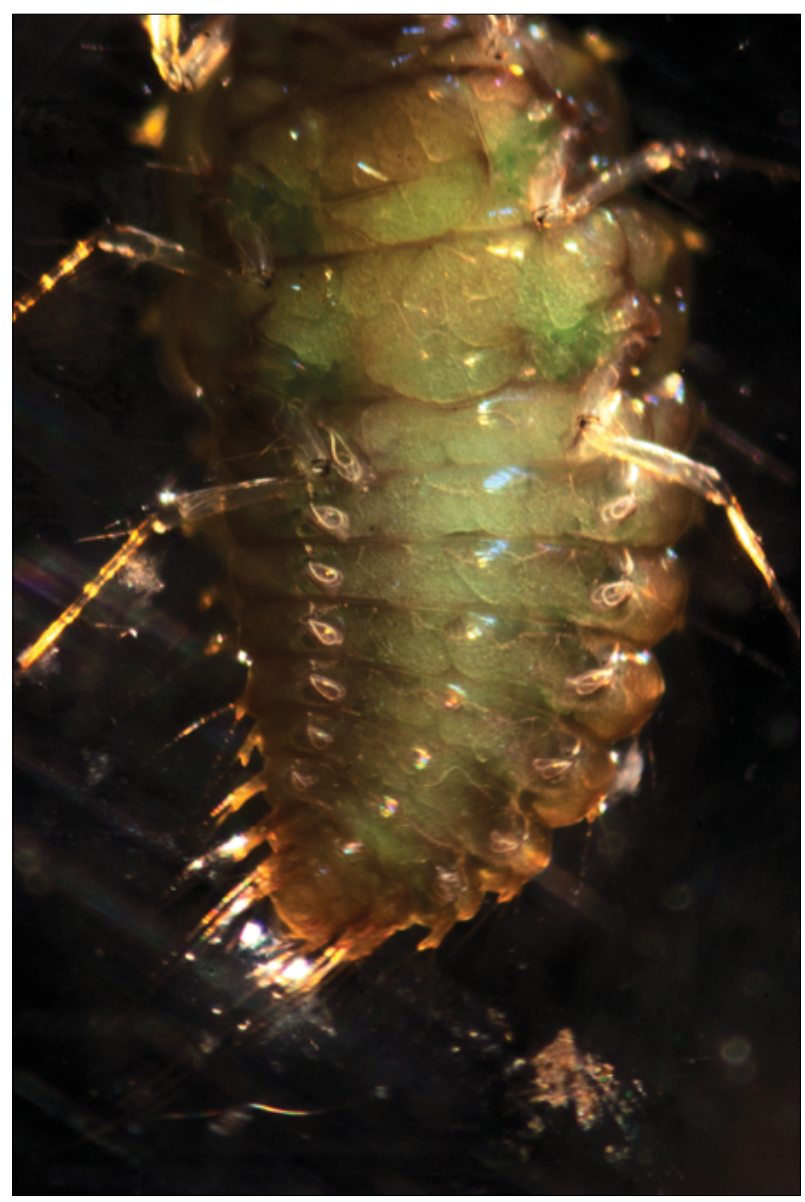

PLATE 2

Abdominal sternites of full-fed Sisyra pedderensis larva after having shed gills (picture taken underwater before insect emerged).
Both the gates and pontoons successfully attracted oviposition (table 1). The clusters of eggs were particularly numerous on the lower surfaces of both types of structure while the upper surfaces were ignored completely. In total $85 \%$ of all oviposition sites observed on the gates $(n=5332)$ and $99.9 \%(n=5709)$ on the pontoons were recorded on the lower surfaces and the remainder on the lateral surfaces. Gates placed $1 \mathrm{~m}$ from the shore attracted the greatest number of oviposition sites. Some eggs also were laid on the gates and sections of the pontoons placed on land.

The eggs of $S$. pedderensis have a mean length $\overline{\mathrm{x}}=0.3$ $\mathrm{mm}$ S.E. $\pm 0.037(\mathrm{n}=30)$ and have a small somewhat flattened micropyle with reticulation present over the chorion (pl. 3). These are laid in clusters of 1-14 eggs. At $20^{\circ} \mathrm{C}$ egg development was completed in 12 days whereas eggs incubated at $10^{\circ} \mathrm{C}$ required 30 days to hatch. The eggs hatched in the early morning as light intensity increased from 185 to 602 lux, i.e., about an hour either side of sunrise (fig. 4).

\section{Larval identification}

The three larval instars were identified using the following external morphological features:

First Instar (length: 0.2-0.4 mm)

The head is the broadest part of the body and is black. The antenna has five segments and basal segment broader and shorter than both second and third segments. The third is longer than the second. The fourth is narrower than the third. The fifth is narrow, acute, and has an apical seta. The third segment bears a distal spine running parallel with the fourth and fifth segments.

TABLE 1

Sisyra pedderensis egg clusters oviposited on horizontal surfaces of wooden gates and pontoons at Starfish Inlet over a two-week period in December 2007 and January 2008. (Counts on horizontal surfaces of gates were from sub-samples covering an area of $75 \mathrm{~cm}^{2}$.)

\begin{tabular}{|c|c|c|c|c|}
\hline \multirow{2}{*}{$\begin{array}{l}\text { Distance } \\
\text { from shore- } \\
\text { line }(M)\end{array}$} & \multirow{2}{*}{$\begin{array}{l}\text { Height }(\mathrm{cm}) \\
\text { above sub- } \\
\text { strate/water }\end{array}$} & \multicolumn{3}{|c|}{$\begin{array}{c}\text { Number of egg clusters on } \\
\text { surfaces }\end{array}$} \\
\hline & & Top & Bottom & Side $\times 2$ \\
\hline \multicolumn{5}{|l|}{ Gates } \\
\hline \multirow[t]{3}{*}{ Land $1 \mathrm{M}$} & 10 & 0 & 22 & 0 \\
\hline & 20 & 0 & 4 & 0 \\
\hline & 30 & 0 & 0 & 0 \\
\hline \multirow[t]{3}{*}{ Water $1 \mathrm{M}$} & 10 & 0 & 1429 & 461 \\
\hline & 20 & 0 & 1170 & 256 \\
\hline & 30 & 0 & 1440 & 37 \\
\hline \multirow[t]{3}{*}{ Water 2M } & 10 & 0 & 259 & 4 \\
\hline & 20 & 0 & 135 & 4 \\
\hline & 30 & 0 & 110 & 0 \\
\hline \multicolumn{5}{|l|}{ Pontoons } \\
\hline Land & 10 & 0 & 475 & 26 \\
\hline $0-1.67 \mathrm{M}$ & 10 & 0 & 2127 & 6 \\
\hline \multirow[t]{2}{*}{$1.67-3.2 \mathrm{M}$} & 10 & 0 & 3058 & 10 \\
\hline & Total & 0 & 10228 & 804 \\
\hline
\end{tabular}




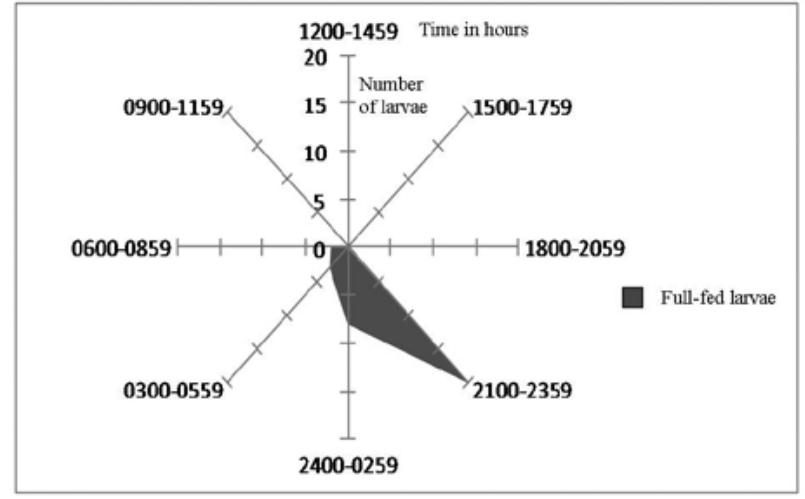

FIG. 3 - Number of full-fed Sisyra pedderensis larvae leaving Lake Pedder in relation to time.

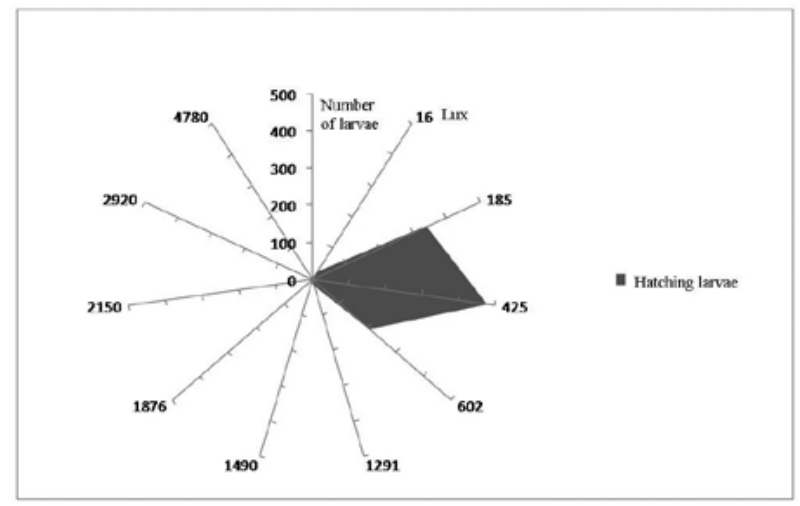

FIG. 4 - Number of larvae of Sisyra pedderensis ecloding from eggs in relation to lux.

Pronotal collar absent. Lateral margins of the pro-, mesoand meta-nota darkly pigmented. The abdomen tapers towards the posterior and external gills are absent. Black setae are present on ninth and tenth abdominal segments (pl. 4).

\section{Second Instar (length: 0.7-2.6 mm)}

Width of head less than prothorax. The antenna has six segments. The second segment is the longest and the third shortest. The fourth is longer than the third and the fifth. The sixth is small and narrow. The fourth segment bears a distal seta which runs parallel to the fifth and extends to about $75 \%$ of the length of the sixth.

Pronotal collar present. Paired gills are present on the sternites of abdominal segments 1-7. Gills are threesegmented with a mid-dorsal ridge running the length of both the first and second gill segments (fig. 5).

Third Instar (length: $2.9-7.1 \mathrm{~mm}$ )

Mean head capsule width $0.424 \mathrm{~mm}$ S.E. $\pm 0.002(\mathrm{n}=50)$ Antennae are greatly elongated, segments variable 11-14. The second segment is about three times the length of the third. Antepenultimate segment bears at its distal end a seta running parallel with penultimate segment. Two short setae are present on distal end of the terminal segment.

The pronotal collar is distinct. A pair of gills occurs on the first seven sternites of the abdominal segments (pl. 5). The first pair of gills is two-segmented and the remaining six are three- segmented. The basal segment of the first pair of
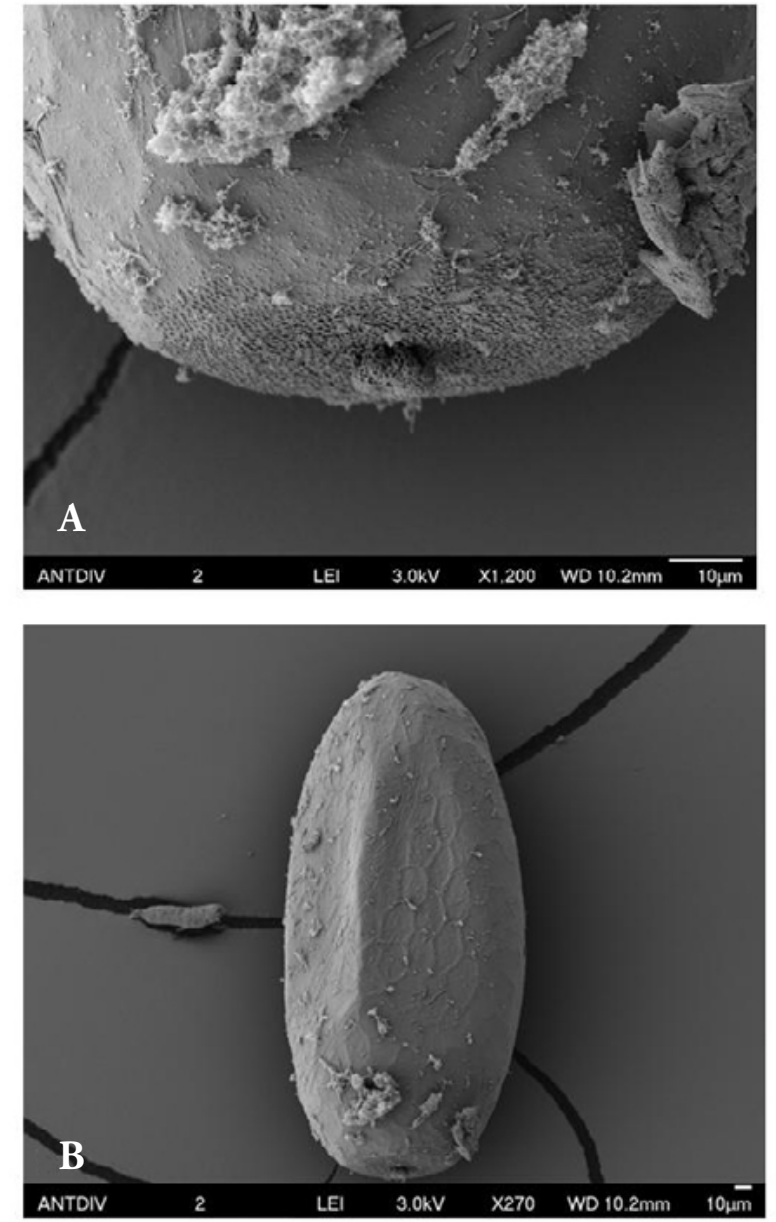

\section{PLATE 3}

(A) SEM image of the micropyle of Sisyra pedderensis egg; and (B) SEM image of $\mathrm{S}$. pedderensis egg showing reticulation on the chorion.

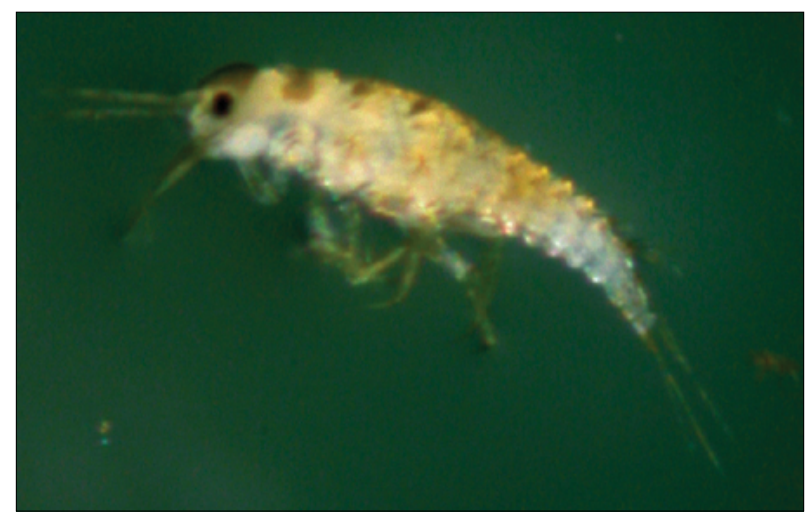

PLATE 4

First instar Sisyra pedderensis larva. Actual length: $0.3 \mathrm{~mm}$.

gills is acutely angled about one-third from the distal end. The basal segments 2-5 are shaped like a boomerang, those of 6 and 7 are less curved. The second segment of gills on abdominal segments 2-7 arise ventrally from beneath the first segment. 


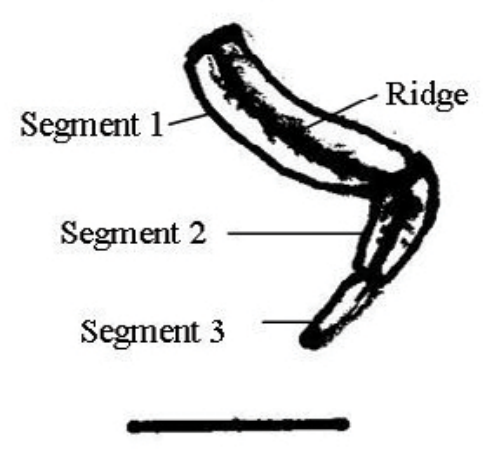

$145 \mu \mathrm{m}$

FIG. 5 - Sisyra pedderensis second instar gill.

Small third instar larvae, mean body length $\overline{\mathrm{x}}=3.8$ mm S.E. $\pm 0.64(n=107)$ overwintered on sponges from April to October. Larvae increased in length in the spring, $\overline{\mathrm{x}}=6 \mathrm{~mm} \mathrm{S.E.} \pm 0.79(\mathrm{n}=86)$ and become full-fed in November/December. All three larval instars were present on sponges in January, February and March, including large third instar larvae.

The cocoon consisted of an outer coarse mesh of silk spun over the top of a much finer, white oval shaped cocoon (length $\bar{x}=3.7 \mathrm{~mm} \mathrm{S.E.} \pm 0.64$ by width $2.6 \mathrm{~mm} \mathrm{S.E.}$ $\pm 0.07(\mathrm{n}=34)(\mathrm{pl} .6))$. The exarate pupa was typically neuropteran, with head and terminal segments of the abdomen bent ventrally. The antennae pass over the head and come to lie along the front margins of the wings. The legs were drawn up towards the body. The third, fourth and fifth abdominal segments were ridged dorsally and bore a number of small sclerotised hooks.

At $20^{\circ} \mathrm{C}$, emergence of the pupa occurred 10 days after the cocoon was spun. However, at $10^{\circ} \mathrm{C}$ the development period was extended to 20 days.

The pupa, on biting a hole in the cocoon, usually emerged completely before revealing the imago. Figure 6 illustrates the timing of adult emergences $(n=294)$. The newly emerged imago expanded its wings within 20 minutes and then deposited a faecal pellet. The majority of emergences usually occurred in the period one hour before and one hour after sunset, and emergence continued until after midnight. However, a not insignificant number of insects emerged in the four-hour period leading up to sunset. On heavily overcast days, there was often a 10 -fold increase in the number of emergences recorded during this four-hour period. The ratio of male to female imagines was $1: 1$.

The majority of imagines mated after dark on the night following emergence. Under laboratory conditions typically both insects fed for several minutes and courtship, which rarely lasted for more than five to ten minutes, followed. Courtship involved raising of the wings followed by short, rapid darts over a substrate often in a circular direction. The male copulated laterally and a spermatophore, $750 \mu \mathrm{m}$ in length, was transferred within three to five minutes. A few minutes after receiving the spermatophore the female was seen to bend her abdomen beneath her thorax and eat a portion of it (pl. $7 \mathrm{a}, \mathrm{b})$. Less than $1 \%$ of newly mated females oviposited on the night they mated.

In laboratory trials, $q$ imagines had a mean life expectancy of 14 days S.E. \pm 3.36 while for $\widehat{\jmath} \overline{\mathrm{x}}=11.5$ days S.E. \pm $4.35(\mathrm{n}=40)$ (fig. 7). The survival means between sexes were

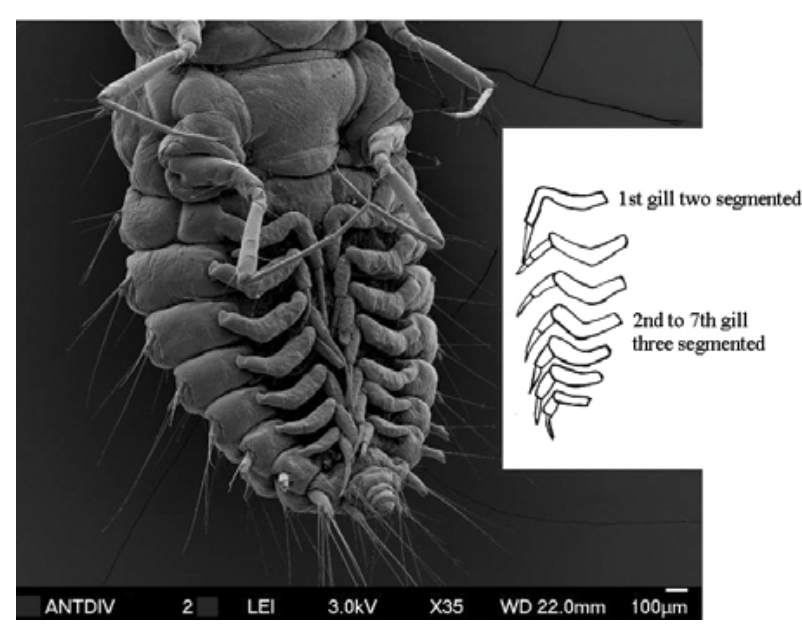

PLATE 5

SEM image of third instar gills of Sisyra pedderensis with diagrammatic inset illustrating numbers of segments.

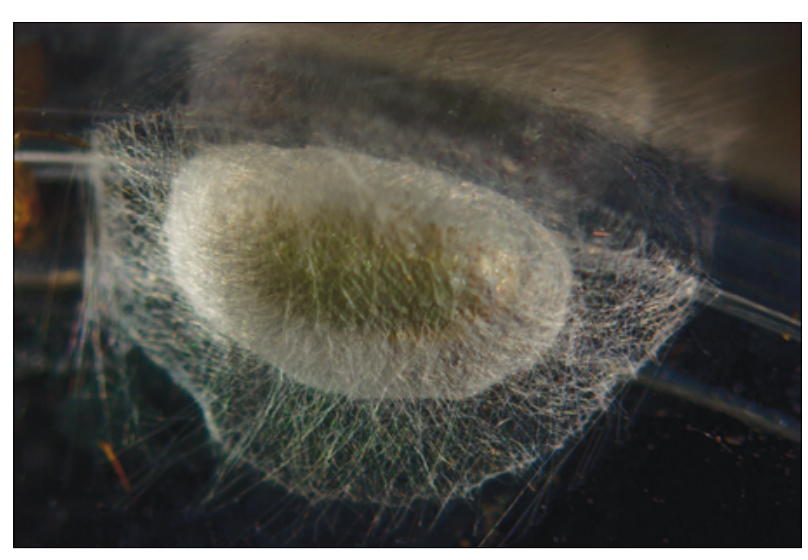

PLATE 6

A tightly spun Sisyra pedderensis cocoon surrounded by a loose net of silk.

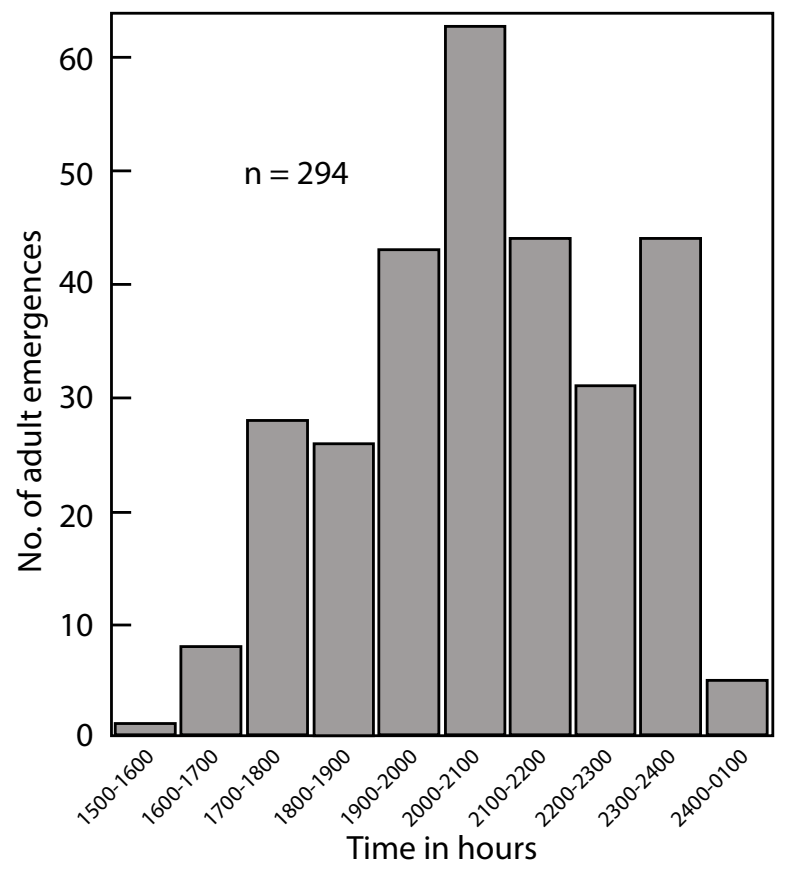

FIG. 6 - Time of adult Sisyra pedderensis emergence. 

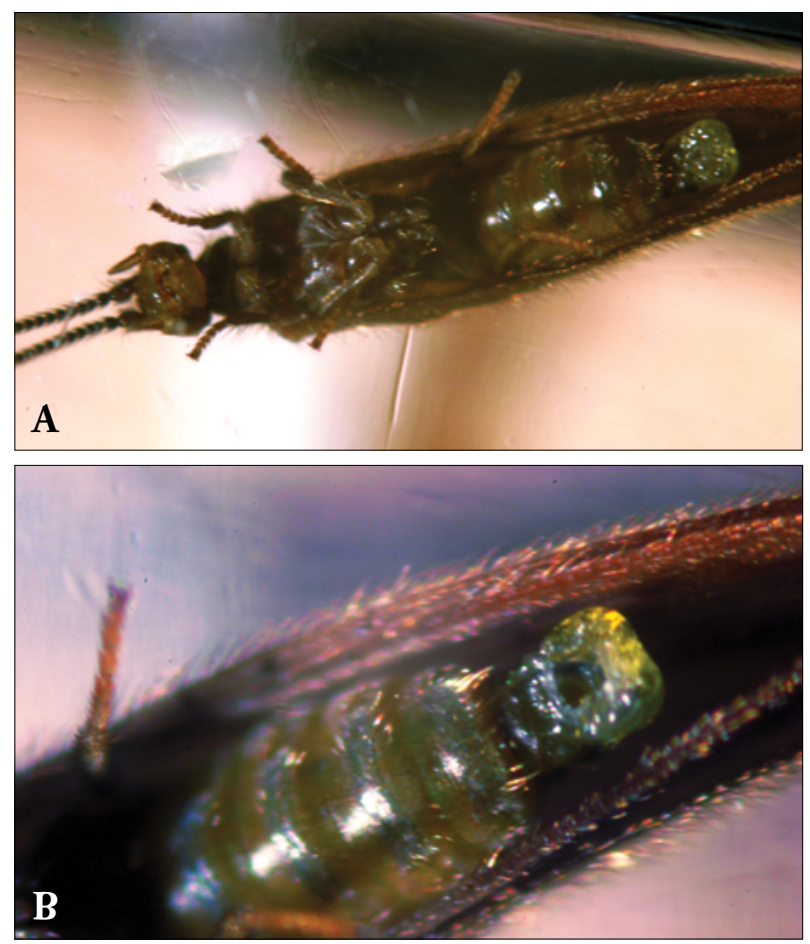

PLATE 7

(A) Female Sisyra pedderensis imago with spermatophore. (B) A hole in a S. pedderensis spermatophore following feeding by the female.

significantly different $\mathrm{t}(78)=2.9, \mathrm{p}=0.005$. One $q$ lived for 28 days and one $\widehat{\partial}$ for 23 days. Oviposition was spread over an average of 11 nights S.E. \pm 3.2 , with a minimum of five and maximum of 19 nights, respectively, during which time $+q+$ oviposited on an average of seven nights S.E. \pm 2.5. However, there was only a weak relationship between the number of nights a female oviposited and the number of eggs she produced (Pearson's $r$ (correlation coefficient) $\left.=0.4006 ; \mathrm{R}^{2}=0.1604\right)$. Broods ranged from as few as 59 eggs to as many as 276 eggs. The greatest number of eggs oviposited by a $q$ on any one night was 140 .

\section{Closure of life cycle in the laboratory}

Eggs were collected from $P_{1}$ imagines at the end of the first week of December. The $F_{1}$ larvae from a single cohort of eggs hatched at dawn 12 days later and larval settlement was confirmed the following morning. Third instar larvae were present on sponges 20 days after the eggs hatched.

A total of 184 full-fed larvae emerged from the water after dark and spun cocoons: 159 of these emerged 30 nights after eclosion, nine larvae 31 nights, and 16 larvae 32 nights, respectively. In total $85 \%$ of the cocoons were spun directly onto hessian sacks and the remainder in fissures on the palings. Imagines emerged after dark 10 days later. No larvae were found on the sponges following these emergences.

The life cycle of the $\mathrm{F}_{1}$ cohort lasted a total 75 days, the last $\mathrm{F}_{1}+$ imago dying 21 days after emergence. In calendar months, the $\mathrm{F}_{1}$ life cycle commenced in the second week of December and was completed in the first week of March. The 15 pairs of $F_{1}$ imagines gave rise to 18 cohorts of $F_{2}$ eggs from which a total of 818 larvae hatched. The first cohort of $\mathrm{F}_{2}$ larvae hatched in the fourth week of February

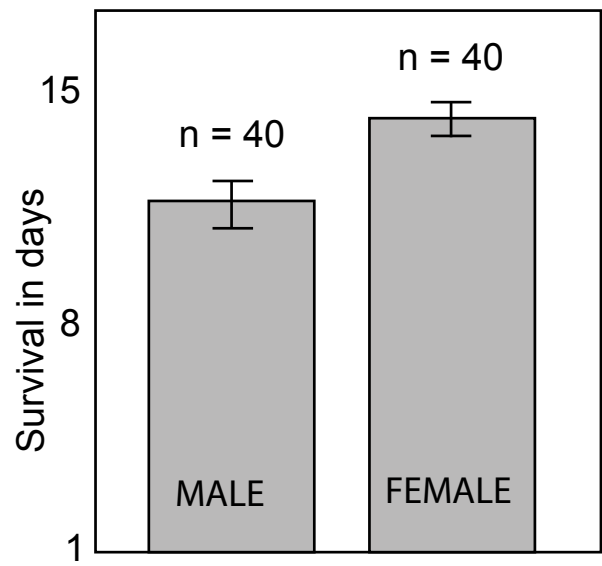

FIG. 7 - Mean survival in days of adult male and female Sisyra pedderensis at $20^{\circ} \mathrm{C}$ (S.E. bars of means are shown).

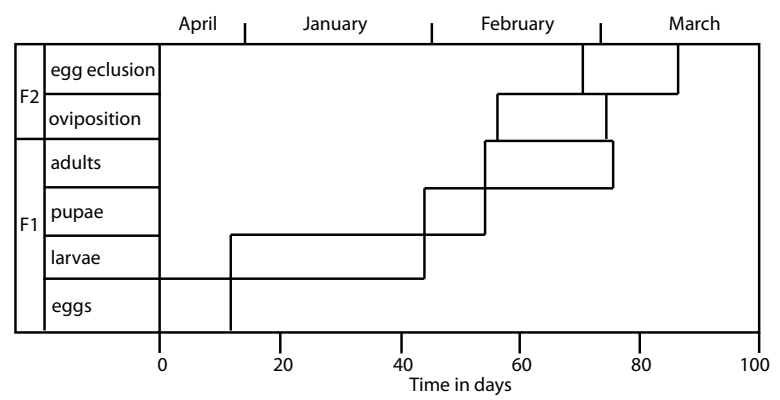

FIG. 8. - Summer life-cycle of Sisyra pedderensis in Lake Pedder.

and the last at the end of the second week of March (fig. 8).

The 30 sponges collected as prey survived the length of the study and were not fouled by algae. The filtration systems were able to maintain water quality at levels considered suitable for fish culture $\left(\mathrm{NH}_{3} \leq 0.025 \mathrm{ppm}\right)$ and dissolved oxygen remained at saturation. $\mathrm{A} \mathrm{pH}$ of 6.5 was recorded throughout the experiment. The water of Lake Pedder is acidic, having a $\mathrm{pH}$ range between 5.6 and 6.8.

\section{DISCUSSION}

Although nine species of Sisyra are known to occur in Australia (Smithers 1973, New 2000, Smithers et al. 2008), and one of these, S. rufistigma Tillyard, 1916 is considered to be conspecific in New Zealand (Wise 1998), their biology, ecology and life cycles are unknown. Furthermore, the larvae of most species have yet to be identified and described (Smithers 1973, Wise 1998). However, New (1992) stated sisyrids are reasonably common in Tasmania but gives no details.

The population of $S$. pedderensis in Lake Pedder possibly is unique in an Australian context in that both the aquatic and terrestrial life stages are locally abundant in many sheltered bays and inlets (Smithers et al. 2008). This probably is partially due to the widespread dispersal and successful settlement of their larval prey, $R$. pedderensis, on inundated timbers and shrubs during the flooding of the Serpentine Valley in the 1970s which resulted in the formation of the present lake (Osborn et al. 2008). An insight into the abundance of spongillaflies within our sampling area at Starfish Inlet is evident from both the large numbers of cocoons spun along the fissures of aerial 
limbs of flooded timbers (pl. 8) and the many hundreds of ovipostion sites observed on the wooden gates and pontoons we placed at Starfish Inlet in January when imagines were on the wing.

\section{Sampling techniques}

Black lights were deployed to no avail on four separate nights when adults were on the wing at both Starfish and Trappes inlets. Therefore, being unable to attract imagines of $S$. pedderensis to ultraviolet lights we were effectively prevented from obtaining data on seasonal peaks and troughs in adult abundance in the field. However, sack-collectors proved an effective sampling method for the collection of meaningful data on the migration of the overwintering full-fed larvae from the lake and in confirming the absence of overwintering prepupae. This sampling method, however, was not effective in defining the summer generation of $S$. pedderensis since it was impossible to know whether the cocoons on the sacks in late December and early January were late cohorts of the overwintering generation or early cohorts of the summer generation. Confirmation of a summer generation was only possible by closing the life cycle in the laboratory.

Detailed early accounts of the biology and ecology of sisyrids are those given by Withycombe (1923, 1925), Killington (1936) and Brown (1952). Later Parfin \& Gurney (1956) published a comprehensive review of the taxonomy, biology, sponge hosts and enemies of various species of Sisyridae with particular reference to the spongillaflies of the Western Hemisphere. Elliott $(1977,1996)$ gives a useful summary of the biology of S. fuscata Fabricius, 1793 and S. terminalis (Curtis, 1854) based on these earlier studies by Withycombe $(1923,1925)$ and Killington (1936) and more recent work by Weissmair (1994), Weissmair \& Waringer (1994). The results of our study on S. pedderensis

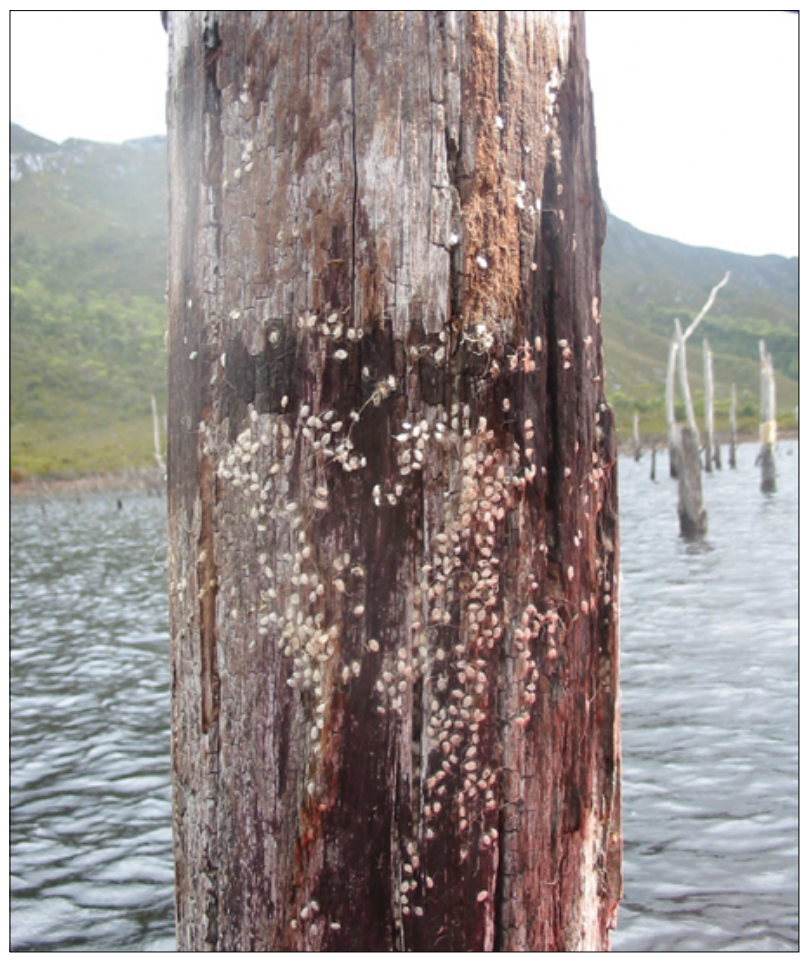

PLATE 8

Sisyra pedderensis cocoons on an aerial trunk in Starfish Inlet. not unexpectedly revealed the biology and ecology of this species have much in common with other species but there are noteworthy exceptions.

\section{Life cycle}

\section{Oviposition}

Spongillafly eggs usually are laid on the undersurface of leaves and branches overhanging water and on eclosion, the larvae fall directly onto the water below (Brown 1952, Weissmair 1994, Weissmair \& Waringer 1994, Hölzel \& Weissmair 2002, Rasmussen \& Pescador 2002). In our study, oviposition sites were present in fissures only on the ventral and lateral surfaces of the wooden gates and pontoons in the field, and wooden blocks placed in the rearing containers in the laboratory. It seems that gravid females actively seek out surfaces on which to oviposit that will be shaded in daylight hours presumably to protect the developing embryos from desiccation and possibly drowning since exposed fissures fill with water in wet weather.

We also found oviposition sites on the ventral surfaces of $G$. grandis several metres from the water's edge. Likewise, oviposition sites were present in not insignificant numbers on those gates and sections of the pontoons placed on the banks of the lake. Pupedis (1986) discovered that the first instar larvae of Climacia areolaris (Hagen, 1861) were able to catapult themselves off a substrate. We do not know if newly hatched larvae of $S$. pedderensis have this ability but if proven it would provide them with a mechanism whereby they might reach the water when eggs were laid over land.

\section{Egg development}

Withycombe (1923) and Brown (1952) were able to show that temperature was an important controlling factor in the development of sisyrid eggs. The development time of 12 days at $20^{\circ} \mathrm{C}$ for the eggs of $S$. pedderensis is in keeping with those reported for other species incubated at similar temperatures (Withycombe 1923, Brown 1952, Parfin \& Gurney 1956). However, the number of generations that $S$. pedderensis is able to complete annually at Lake Pedder may partially be controlled by the duration of the developmental period of both eggs and pupae. At $10^{\circ} \mathrm{C}$, the development period of both these life stages was extended. It certainly is not unusual even in summer at this Tasmanian location to experience ambient air temperatures close to $10^{\circ} \mathrm{C}$ especially when low pressure fronts push north from the Southern Ocean.

\section{Eclosion}

Eclosion of spongillafly larvae from eggs usually occurs at night (Brown 1952, Pupedis 1986, Weissmair \& Waringer 1994). Hatching of the larvae of $S$. pedderensis, on the other hand, was restricted to the period of first light at dawn. The larvae of $S$. pedderensis are demonstrably photo-negative, a behavioural trait which possibly enhances survival by forcing the newly hatched larvae down into the heavily tanninised water of Lake Pedder and away from increasing light intensity on the water surface as the sun rises. Weissmair (1994) noted that newly-hatched larvae of $S$. fuscata drifted for 24-168 hours depending on water temperature before settling on their sponge or bryozoan hosts. In the laboratory, we never observed the larvae to drift in the water column for more than an hour or two at most and the majority of larvae usually had settled on their prey within one hour of eclosion. 


\section{Larval morphology and identification}

We developed simple morphological descriptions to allow us to identify the three larval instars of $S$. pedderensis based on keys and descriptions provided by Withycombe (1923), Parfin \& Gurney (1956), Poirrier \& Arceneaux (1972), Elliott (1996), Weissmair \& Waringer (1994) and Rasmussen \& Pescador (2002). Larval gills, in particular, have proved useful in differentiating between intra- and inter-larval instars (Poirrier \& Arceneaux 1972, Elliott 1996, Weissmair \& Waringer 1994, Rasmussen \& Pescador 2002). The gills of second and third instars of $S$. pedderensis differ markedly and provide a useful morphological feature by which to tell them apart. It should be noted that the fourth segment of the antenna of the second instar of $S$. pedderensis bears a distal seta which runs parallel to the fifth segment and only part not all of the sixth segment as in $C$. areolaris (Parfin \& Gurney, 1956). Parfin \& Gurney (1956) have reviewed the reported body lengths of third instar larvae for several species: it appears that the body lengths of third instar larvae of $S$. pedderensis are slightly greater than those given by these researchers and Weissmair \& Waringer (1994) and Elliott (1996) for S. fuscata and S. terminalis.

\section{Diapause}

It is apparent from sampling cocoons from diverse locations within Lake Pedder that $S$. pedderensis does not have a diapausing overwintering prepupal stage at this geographical location at least. The majority of larvae of $S$. pedderensis overwinter as small third instars preying on sponges.

\section{Pupation}

The majority of full-fed larvae of $S$. pedderensis migrated from the water to pupate at night; this behaviour being similar to that recorded for $C$. areolaris by Rasmussen $\&$ Pescador (2002). In Starfish Inlet cocoons were spun on the aerial limbs of flooded timbers sometimes less than a metre above the water surface. Along the western shore of Sprent Basin, however, where there were no flooded trees, cocoons were found up to $30 \mathrm{~m}$ from the water's edge under the bark of eucalypts, among exposed root-stocks of L. lanigerum, and tussocks of G. grandis, as well as in tangled mats of Juncus articulatus L. washed up along the shore. Several researchers have commented on the opportunistic nature of larvae when searching for suitable pupation sites (Withycombe 1923, Brown 1952, White 1976). The time taken to spin a cocoon by $S$. pedderensis appears to be similar to that reported by Needham \& Betten (1901) for S. vicaria (Walker, 1853), and Withycombe (1923), Brown (1952) and Poirrier (1969) for C. areolaris. However, the prepupa of $S$. pedderensis undergoes metamorphosis to the pupal stage more rapidly.

\section{Courtship and mating}

Our observations on the courtship and mating behaviour of $S$. pedderensis are similar to those described for other species by Withycombe (1923), Brown (1952), Parfin \& Gurney, (1956), Elliott (1977) and Pupedis (1987). However, in the laboratory mating by $S$. pedderensis usually occurred on the night after emergence. We never observed courtship or mating taking place later than this, whereas mating in both $C$. areolaris and $S$. fuscata is reported to occur a few hours to two weeks after emergence (Brown 1952, Elliott 1977). Brown (1952) collected imagines of $C$. areolaris copulating in flight on one occasion but we have no evidence of similar behaviour by $S$. pedderensis.

\section{Feeding}

In the wild, spongillafly imagines are reported to feed on pollen, aphids, plant mites, and even on the eggs of the alderfly Sialis lutaria Linnaeus, 1758 (Tjeder 1944, Brown 1952, Kokubu \& Duelli 1983, Pupedis 1987, Monserrat 2005). Kokubu \& Duelli (1983) and Stelzl (1991) found $S$. terminalis and $S$. fuscata also fed on honeydew to which was stuck various particles such as pollen grains, fungal spores and algae. Stelzl (1992) discussed the structure of the mouthparts of spongillaflies and suggested the modified lacinia were the principal organs for spooning up nectar while the grooved maxillary palps were used for catching small prey such as mites. The gut of $S$. pedderensis adults collected from the riparian vegetation at Starfish Inlet and Sprent Basin contained only clear fluid in which small particles, probably fungal spores, were embedded. We concluded these insects were feeding on honeydew.

\section{Longevity of imagines}

The longevity of spongillafly imagines in the wild is seldom reported but within a generation, adults appear to be on the wing for 4-6 weeks (White 1976, Andersen \& Greve 1975, Elliott 1977, 1996, Weissmair 1994, Weissmair \& Waringer 1994). In the laboratory, $q$ q $q$ of $S$. pedderensis lived longer than $\hat{\partial} \delta$ but relatively few insects survived for more than 17 days. Brown (1952) managed to keep one insect alive for 21 days and we recorded a female surviving for 28 days. Oviposition was drawn out over as many as 19 nights but 11 on average, during which $q+$ actually oviposited on an average of seven nights. A single generation of $S$. pedderensis, therefore, consists of a large number of cohorts and although longevity of individual insects may be short, each generation is on the wing for at least a month at Lake Pedder.

Clifford (1982), in a review of the life cycles of the Ephemeroptera, pointed out that it was not always clear what was meant by a cohort and suggested that ideally nymphs of the same cohort should all transform at or about the same time. Indeed this was found to be the case in our study. The larvae all hatched on the same morning, and emerged full-fed from the water to pupate over a relatively short period of three nights. Furthermore, no larvae remained on the sponges in the aquarium after this emergence period.

\section{Voltinism}

Research on spongillaflies shows that the more thoroughly a species is studied throughout its range, often the more flexible the life cycle is found to be. Withycombe (1923, 1925) for example offers circumstantial evidence to suggest S. fuscata is multivoltine but Killington (1936) and Andersen \& Greve (1975) are more specific believing the species to be bivoltine. Killington (1936), Kimmins (1962), Weissmair (1994), Ellliott (1996) and Hölzel \& Weissmair (2002) point out that at some locations $S$. fuscata has a complex life cycle which includes a diapausing winter generation of prepupae within cocoons and also a rapidly-developing summer generation. Langford (1975) deduced from the results he obtained from trapping imagines of $S$. terminalis in emergence traps along the banks of the River Severn in England that this species was univoltine, a view shared by Elliott (1996). In Austria, Weissmair (1994) and Hölzel \& Weissmair (2002) reported S. terminalis to have a complex life cycle similar to that of $S$. fuscata. White (1976) found that $C$. areolaris had five distinct generations per year in Lake Texoma, Texas and Oklahoma, whereas Brown (1952) suggested three, possibly four, while in the State of New 
York Needham \& Betten (1901) considered the species to be bivoltine. White (1976) attributed these differences in voltinism of $C$. areolaris to climate, reflected in seasonal water temperature which would allow a longer growing season for sponges and consequently the production of more broods. At Lake Pedder, we suspect ambient air temperatures may exert a more immediate and tangible control on voltinism of $S$. pedderensis than the growth of $R$. pedderensis as this freshwater sponge is abundant throughout the year.

Studies on the voltinism of sisyrids have relied mostly on demonstrating peaks and troughs in abundance of imagines attracted to ultraviolet-blacklights (Tjeder 1944, Andersen \& Greve 1975, White 1976, Kokubu \& Duelli 1983, Weissmair 1994, Ramussen \& Pescador 2002). Weissmair (1994) used both light-trapping and the laboratory rearing of eggs, larvae and adults to determine the number of generation of $S$. fuscata and $S$. terminalis in his studies. In our work, it has been necessary to close the life cycle of $S$. pedderensis in the laboratory to show that in Lake Pedder this species has a bivoltine winter-summer cycle; that is an overwintering generation in the larval stage and one summer generation in accordance with Clifford (1982).

\section{Rearing techniques and developmental lengths}

Benke et al. (1984) point out that some researchers feel that laboratory growth studies under "ideal" conditions result in development times that are shorter than actually occur in nature. For this reason we maintained the water temperature in our aquarium at $18^{\circ} \mathrm{C}$ to ensure it was similar to that recorded at Lake Pedder during the time the summer generation of larvae was expected to be present.

Likewise, many studies on aquatic insect larvae generally support the view that growth of a given species is sensitive to food quality and quantity (Clifford 1982, Chapman 1972, Aston 1973, Mackey 1976, Anderson \& Cummins 1979, Milton Ward \& Cummins 1979, Menzie, 1981, Benke et al. 1984, Campbell et al. 1998). Weissmair (1994) and Weissmair \& Waringer (1994) point out that spongillafly larvae only colonise fully vital freshwater sponges. Other researchers have highlighted difficulties in rearing larvae on sponges due to the rapid mortality of the latter when fouled by algae (Withycombe 1923, Old 1933, Brown 1952). We endeavoured to maintain the quality of the prey by providing whole, undamaged sponges and reducing light intensity in the aquarium room to prevent the sponges becoming fouled by algae. The quantity of prey, on the other hand, was predetermined by the available surface area on which to place the sponges on the bottom of the aquarium and our preconceived surfaces on which to pupate. Thus we have no reason to believe the 30 -day period of larval development in the aquarium to be dissimilar to that of larval development in Lake Pedder between late December and the end of February.

\section{Generation lengths}

Rapidly developing summer generations of $S$. fuscata have been reported by Killington (1936), Kimmins (1962) and Elliott, (1977, 1996) in England, and Weissmair (1994) and Hölzel \& Weissmair (2002) have provided evidence of rapidly developing summer generations of both $S$. fuscata and $S$. terminalis in Austria. These summer generations were completed within about three months. From figure 8 it can be seen that the summer generation of $S$. pedderensis required two and a half months to complete under laboratory conditions. Eclosion of the $\mathrm{F}_{2}$ larvae did not commence until the end of
February with hatching of eggs continuing until mid-March. At Lake Pedder, both air and water temperatures are in decline from mid-March onwards and the development period of eggs must slow with many larvae not entering the water before April. Most of these larvae reach the third instar stage before the winter minimum water temperature. Weissmair (1994) and Hölzel \& Weissmair (2002) found that larvae derived from eggs laid in summer (August) overwintered as first and second instar larvae in their study area in Austria, and Loru et al. (2005) established that $S$. iridipennis Costa, 1884 overwintered as first instars in NW Sardinia. Third instars of $S$. pedderensis do not become full-fed until NovemberDecember when water temperatures are again on the rise. These results show that $S$. pedderensis indeed has a bivoltine winter-summer life cycle in Lake Pedder.

To date, $S$. pedderensis has been found only in (a) Lake Pedder and (b) Edgar Dam. It remains to be seen whether the biology, ecology and bivoltine winter-summer life cycle of $S$. pedderensis described herein differ from other populations of as yet undiscovered populations or indeed other Australian sisyrids in general.

\section{ACKNOWLEDGEMENTS}

From Hydro Tasmania we sincerely thank Messrs J. Ford, S. Gartenstein and C. Livingston for invaluable coxswain assistance; we also are indebted to B. Smith for the provision of planning, logistical and back-up support for work on the lake; and we express our genuine appreciation to B. Brady for assistance over many years on numerous issues that arose in a remote setting with reference to our field studies on Lake Pedder. We greatly appreciate the contributions of R. van den Enden, Electron Microscopist with The Australian Antarctic Division, that resulted in the production of the SEM images. The research was made possible by grants from Hydro Tasmania and the W. D. Booth Charitable Trust. Finally, considerable valuable support has been forthcoming from the Queen Victoria Museum \& Art Gallery, Launceston.

\section{REFERENCES}

Andersen, T. \& Greve, L. 1975: Neuroptera in light-traps at Osteroy, Hordaland. Norwegian Entomologist 22: 12-128.

Anderson, N.H. \& Cummins, K.W. 1979: Influences of diet on the life histories of aquatic insects. Journal of the Fisheries Research Board of Canada 36: 335-342.

Aston, R.J. 1973: Field and experimental studies on the effects of a power station effluent on Tubificidae (Oligochaeta, Annelida). Hydrobiologia 42 (2-3): 225-242.

Benke, A.C., Van Arsdall, T.C., Gillespie, D.M. \& Parish, F.K. 1984: Invertebrate productivity in a subtropical Blackwater River: the importance of habitat and life history. Ecological Monographs 54 (1): 25-63.

Brown, H.P. 1952: The life history of Climacia areolaris (Hagen), a neuropterous "parasite" of freshwater sponges. American Midland Naturalist 44: 130-160.

Campbell, I.C., Parnrong, S. \& Treadwell, S. 1998: Food availability and life history patterns of aquatic insects in evergreen eucalypt forest streams in Southwestern Australia. Verhbandlung des Internationalen Verein Limnologie 26: 986-989.

Chapman, R.F. 1972: The Insects, Structure and Function. English University Press London: 819 pp.

Clifford, H.F. 1982: Life cycles of mayflies (Ephemeroptera), with special references to voltinism. Quaestionnes Entomologicae 
18: 15-90.

Elliott, J.M. 1977: A key to the Larvae and Adults of British Freshwater Megaloptera and Neuroptera with notes on their life cycles and ecology. Freshwater Biological Association, Scientific Publication 35, Ambleside: 52 pp.

Elliott, J.M. 1996: British Freshwater Megaloptera and Neuroptera: a key with ecological notes. Freshwater Biological Association, Scientific Publication No. 54, Ambleside: 69 pp.

Forteath, G.N.R. \& Osborn, A.W. 2012: Survival of endemic invertebrates of Lake Pedder and Lake Edgar subsequent to inundation. Records of the Queen Victoria Museum 116: 26 pp.

Forteath, G.N.R., Osborn, A.W. \& Askew, R.R. 2010: Trichomalopsis sisyrae Askew, Sp. Nov. (Hymenoptera: Pteromalidae) a parasitoid of Sisyra (Neuroptera: Sisyridae) in Tasmania, Australia. Papers and Proceedings of the Royal Society of Tasmania 144: 15-19.

Hölzel, H. \& Weissmair, W. 2002: Band 16. Insecta: Neuroptera. In Schwoerbel, J. \& Zwick, P. Süsswasserfauna von Mitteleuropa. Band 15-17. Insecta: Megaloptera, Lepidoptera. Spektrum Akademischer Veriag, HeidelbergBerlin: 31-38.

Killington, F.J. 1936: A monograph of British Neuroptera. Ray Society, London 1: 306 pp.

Kimmins, D.E. 1962: Keys to the British Species of Aquatic Megaloptera and Neuroptera with Ecological Notes. Freshwater Biological Association, Scientific Publication Number 8, Ambleside: 21 pp.

Kokubu, H. \& Duelli, P. 1983: Adult food of sponge flies: observations on the crop and gut content of Sisyra terminalis Curtis (Planipennia: Sisyridae). Neuroptera International II (3): 157-162.

Langford, T.E. 1975: The emergence of insects from a British river, warmed by power station cooling-water. Hydrobiologia 47: 91-113.

Loru, L., Pantaleoni, R.A. \& Sassu, A. 2005: Overwintering stages of Sisyra iridipennis A.Costa, 1884 (Neuroptera: Sisyridae). Annali del Museo civico di Storia naturale di Ferrara 8 (2007): 153-159.

Mackey, A.P. 1976: Quantitative studies of the Chironomidae (Diptera) of the River Thames and Kennet.11. The Flint Zone. Archiv für Hydrobiologie 78 (3): 310-318.

Menzie C.A. 1981: Ecology of Cricotopus sylvestris (Fabricius) (Diptera: Chironomidae) in a shallow estuarine cove. Limnology and Oceanography 26 (3): 467-481.

Milton Ward, G. \& Cummins, K.W. 1979: Effects of food quality on growth of a stream detritivore, Paretendipes albimanus (Meigen) (Diptera: Chironomidae). Ecology 60 (1): 57-64.

Monserrat, V.J. 2005: Nuevos datos sobre algunas pequeńas familias de neurópteros (Insecta: Neuroptera: Nevrorthidae, Osmylidae, Sisyridae, Dilaridae). Heteropterus Revista Entomologia 5: 1-26.

Needham, J.G. \& Betten, C. 1901: Aquatic insects in the Adirondacks. New York State Museum Bulletin 47: 383-612.

New, T.R. 1992: The lacewings (Insecta, Neuroptera) of Tasmania. Papers and Proceedings of the Royal Society of Tasmania 126: 29-45.

New, T.R. 2000: Neuroptera: In Naumann, I.D. (ed.): The Insects of Australia. Melbourne University Press: 1137 pp.

Old, M.C. 1933: Observations on the Sisyridae (Neuroptera): Papers of the Michigan Academy of Science, Arts and Letters 17: 681-684.

Osborn, A.W., Forteath, G.N.R. \& Stanisic, J. 2008: A new species of freshwater sponge (Porifera: Spongillidae) of the genus Radiospongilla from Lake Pedder in Tasmania. Papers and Proceedings of the Royal Society of Tasmania 142 (2): 39-44.

Parfin, S.I. \& Gurney, A.B. 1956: The spongilla-flies, with special reference to those of the Western Hemisphere (Sisyridae, Neuroptera). Proceedings of the United States National Museum 105: 421-529.
Poirrier, M. 1969: Some fresh-water sponge hosts of Louisiana and Texas Spongilla-flies, with new locality records. American Midland Naturalist 81: 573-575.

Poirrier, M. \& Arceneaux, Y.M. 1972: Studies on the Southern Sisyridae (Spongilla-flies) with a key to the third-instar larvae and additional sponge-host records. American Midland Naturalist 88 (2): 455-458.

Pupedis, R.J. 1986: Hatching behaviour of sisyrid larvae (Neuroptera: Sisyridae). Neuroptera International IV(1): 53-55.

Pupedis, R.J. 1987: Foraging behavior and food of adult spongillaflies (Neuroptera, Sisyridae). Annals of the Entomological Society of America 80 (6): 758-760.

Rasmussen, A. K. \& Pescador, M.L. 2002: A guide to the Magaloptera and Aquatic Neuroptera of Florida. Florida Dept. of Environmental Protection Publication: 45 pp.

Smithers, C.N. 1973: A new species and new records of Sisyridae (Neuroptera) from Australia. Australian Entomological Magazine 1 (3): 19-21.

Smithers, C.N., Forteath, G.N.R. \& Osborn, A.W. 2008: A new species of Sisyra Burmeister (Insecta: Neuroptera: Sisyridae) from Lake Pedder, Tasmania. Australian Journal of Entomology 47: 77-79.

Stelzl, von M. 1991: Untersuchungen zu Nahrungsspektren mitteleuropaischer Neuropteren-Imagines (Neuropteroidea; Insecta). Journal of Applied Entomology 111: 469-477.

Stelzl, M. 1992: Comparative studies on mouthparts and feeding habits of adult Raphidioptera and Neuroptera (Insecta: Neuropteroidea). Proceedings of the Fourth International Symposium of Neuropterology 341-347.

Tauber, M.J. \& Tauber, C.A. 1978: Evolution of phenological strategies in insects: a comparative approach with ecophysiological and genetic considerations pp. 53-71. In $\mathrm{H}$. Dingle (ed.): Evolution of Insect Migration and Diapause. Springer-Verlag, New York: 284 pp.

Tjeder, B. 1944: A note on the food of the adult Sisyra fuscata Fabricius (Neuroptera: Sisyridae). Entomologisk Tidskrift 65: 203-204.

Weissmair, W. 1994: Eidonomie und Okologie zweier europaischer Schwammfliegen-Arten (Neuroptera: Sisyridae). Entomologia Generalis 18 (3/4): 261-272.

Weissmair, W. \& Waringer, J. 1994: Identification of the larvae and pupae of Sisyra fuscata (Fabricius) and Sisyra terminalis Curtis, 1854, (Insecta: Planipennia: Sisyridae), based on Austrian material, Aquatic Insects. International Journal of Freshwater Entomology 16 (3): 147-155.

White, D.S. 1976: Climacia areolaris (Neuroptera: Sisyridae) in Lake Texoma, Texas, Oklahoma. Entomological News, Philadelphia 87: 287-291.

Wise, K.A.J. 1998: A species of the family Sisyridae (Insecta: Neuroptera) in New Zealand. New Zealand Entomologist 21: $11-16$.

Withycombe, C.L. 1923: Notes on the biology of some British Neuroptera (Planipennia). Transactions of the Entomological Society of London 1922: 501-594.

Withycombe, C.L. 1925: Some aspects of the biology and morphology of Neuroptera. With special references to the immature stages and their possible phylogenetic significance. Transactions of the Entomological Society of London 1924: 303-401.

(accepted 2 September 2012) 